J. Product. \& Dev., 25(3): 307-321 (2020)

\title{
EFFECTIVENESS OF SOME SYNTHETIC INSECTICIDES AGAINST THE WHITEFLY, Bemisia tabaci ON TOMATO, Lycopersicon esculentum MILL. AND INFESTATION IMPACTS ON CERTAIN PHOTOSYNTHETIC PIGMENTS CONCENTRATIONS OF TOMATO PLANT LEAVES
}

\section{A.E. Bughdady ${ }^{1}$, Abdel Hamed H. Mohanna ${ }^{1}$ and Tarek R. Amin ${ }^{2}$}

1. Plant Protection Dept., Fac. Develop. Technol., Zagazig Univ., Zagazig, Egypt

2- Plant Protection Research Institute, Dokki, Giza, Egypt.

*corresponding author: Ahmed A. Bughdadi, Tel.: +01285353497

E- mail address: Sama.pestcontrol@ gmail.com

\section{ABSTRACT}

Field experiments were carried out at Al-Quaren village, Sharkia governorate during seasons 2016 and 2017 to evaluate the efficiency of three synthetic insecticides belonging to two groups, synthetic pyrethroid (lambda-cyhalothrin) and neonicotinoids (thiamethoxam and acetampride) towards the tomato whitefly, Bemisia tabaci on tomato crop. As for, estimation of certain pigments content of fresh tomato leaves (chlorophyll $a$, chlorophyll $b$ and carotenoids) had been conducted. The experiments were verified on randomized complete block design (RCBD) with three treatments Viz., $T_{1}$; thiamethoxam (Actara $25 \% \mathrm{WP}, 0.58 \mathrm{~g} / 2.88 \mathrm{~L}$ ), $\mathrm{T}_{2}$; acetampride (Mospilan $20 \% \mathrm{SP}, 0.72 \mathrm{~g} /$ 2.88L), $T_{3}$; lambda-cyhalothrin (Cyhalothrin $5 \% \mathrm{EC}, 1.44 \mathrm{Cm}^{3} / 2.88 \mathrm{~L}$ ) and control. All treatments were repeated three times.

The results revealed that all treatments of whitefly populations dropped in appreciable levels during 2016 and 2017 seasons. Furthermore, the results showed that the treatment after spraying with lambda-cyhalothrin gave the highest reduction in whitefly populations followed by 86.61, 71.99 and $67.80 \%$, respectively, within 14 days of post- treatment. Respecting the impact of B. tabaci infestation on tomato pigments, the results showed that there were highly significant differences in all the mean content of pigments (chlorophyll $a, b$ and carotenoids) in intact tomato leaves compared with the infested tomato leaves. The mean contents of chlorophyll A, B and carotenoids in intact 
tomato leaves were $9.155 \pm 0.134,2.355 \pm 0.126$ and $2.436 \pm 0.053 \mathrm{mg} / \mathrm{g}$ fresh tomato leaves, respectively, while in infested tomato leaves were $8.427 \pm 0.710,2.053 \pm 0.288$ and $2.759 \pm 0.274 \mathrm{mg} / \mathrm{g}$ fresh tomato leaves, respectively.

In conclusion, it could be recommended using lambda-cyhalothrin besides thiamethoxam in combating the tomato whitefly, B. tabaci, in integrated pest management (IPM).

Key words: Syntheti insecticides, Bemisia tabaci, certain photosynthetic pigments

\section{INTRODUCTION}

Tomato, Lycopersicon esculentum Mill., is a vegetable crop of large importance throughout the world. It is the first horticultural crop in Egypt (Radwan and Taha, 2012). The crop is infested with a number of sucking insect pests in vegetative stage and borers at fruiting stage. Among the sucking insects, the tomato whitefly, Bemisia tabaci (Gennadius) (Hemiptera: Aleyrodidae) is one of the most destructive pests all over the world especially in tropical and subtropical regions (Toscano et al., 1994 and Denholm et al., 1996), and also acts as vector of tomato leaf curl virus (Dempsey et al., 2017). It is widely distributed (Boykin et al., 2007 and Dinsdale et al., 2010) and affects over 900 host plants (GISD, 2012). It cause direct and indirect damage to the tomato especially in the early growth stage. Both nymphs and adults suck the cell sap from the lower leaf surfaces. In addition, they disrupt transportation in conducting vessels and apparently introduce a toxin that impairs photosynthesis in proportion to the amount of feeding (Sharma and Chander, 1998). When several insects suck the sap from the same leaf, yellow spots appear on the leaves, followed by crinkling, curling, bronzing, and finally drying of the leaves. In case of severe damage, all leaves of the plants become crinkled or twisted with drastic reduction in photosynthesis which ultimately causes severe yield reduction. Also, this insect pest is a potential vector of various viruses including tomato leaf curl, and its honey dew attracts black sooty mould which inhibits photosynthesis thus reducing the yield.

Neonicotinoid insecticides are compounds acting agonistically on insect nicontinic acetylcholine receptors (nACHR). They are especially active 
on hemipteran pest species such as aphids, whiteflies and plant hoppers, but also recommended to control many coleopterans and some lepidopteran pest species (Nauen et al., 2003).The benefits of using systemic insecticides (thiamethoxam and acetampride) over contact insecticides is that in most cases they provide continuous plant protection through most of the growing season without the need for repeated applications. In addition, systemic insecticides are not susceptible to ultra violet light degradation or "wash off" during watering and the risk of over exposure to applicators is minimized (Herbert et al., 2008). Although insecticidal control is one of the common methods against whitefly on various vegetative crops, tomato being a vegetative crop, use of broad- spectrum insecticides will leave considerable toxic residues on the fruits and may cause considerable health hazards (Sehuster et al., 2010).

So, the aim of the present study to evaluate the effectiveness of some synthetic insecticides belonging to two groups, neonicotinoids (thiamethoxam and acetampride) and synthetic pyrethroid (lambda-cyhalothrin) for the control of $B$. tabaci and to evaluate their residual effects on the reduction of B. tabaci population. In addition, the impact of $B$. tabaci infestation on certain tomato pigments (Chlorophyll A, Chlorophyll B and Carotenoids) was determined.

\section{MATERIALS AND METHODS}

\section{Insecticides used}

Lambda-cyhalothrin (Cyhalothrin, synthetic pyrethroid, 5\% E.C., 50 cm/100 L, acetampride (Mospilan, neonicotinoid, 20\% SP, $25 \mathrm{~g} / 100 \mathrm{~L}$ and thiamethoxam (Actara, neonicotinoid, 25\%, $20 \mathrm{~g} / 100 \mathrm{~L}$ ).

\section{Toxicity experiments:}

The study was carried out at Quraen village, Sharkia governorate, to compare the toxicity of different synthetic insecticides recommended (acetamipride and thiamethoxam) and used (lambda-cyhalothrin) against the tomato whitefly, B. tabaci on tomato GS cultivar during season 2016 and 2017. Plot size area was $121 \mathrm{~m}^{2}$, the distance between rows, $1.00 \mathrm{~m}$ whereas, between plants distance $0.60 \mathrm{~m}$. The experiment was planted in a randomized complete block design (RCBD), the selected plants were sprayed with three 
different insecticides previously agreed upon. The plants left without any contamination, using normal water of application, and commit to repeat three times. Five plants/row from each treatment were randomly represented in such a sequence of two leaves from the lower canopy two from the middle canopy and one leaf from the top of the branch. All agronomic practices were maintained constantly when required the treatment according to the plot area, calibrated and sprayed according to the schedule with an interval of 15 days from first occurrence of the insect pest i.e., 30 days after planting.

Observations on the count of both whitefly nymphs and adults were recorded for thirty randomly selected plants before any treated for plot. Three leaves were randomly selected from each plant, then the count of whitefly populations were taken carefully (since the adults are highly mobile) from the lower side of each leaf and the nymphs by using 20x lens. Finally, the results were expressed as mean populations/3 leaves/plant. First count was taken one day before first spray and post-treatment counts were taken 1, 3, 5, 7, 9 and 14 days after each spray. The percent reduction in insect population was calculated according the equation of Henderson and Tilton (1955).

\section{Estimation of tomato leaves pigments content}

The data were collected from five randomly selected plants for each of non-infested (control) and infested cultivar with B.tabaci (Five leaves from each plant) after six weeks of transplanting. The photosynthetic pigments (chlorophyll a, b and carotenoids) were extracted from the second fresh leaves of the tomato plant using pure acetone according to Fadeel (1962). The optical densities were measured spectrophotometrically at 664.5, 647 and $452.5 \mathrm{~nm}$, for chlorophyll a, b and carotenoids, respectively.

\section{Statistical analysis}

The data were compiled and tabulated for statistical analysis. Infestation reduction percentages with whitefly, B. tabaci at different periods of post- treatment were subjected to analysis of variance (ANOVA) to determine the statistical significance of treatments using the SPSS 14.00 software (SPSS Inc. Chicago, Il, USA). Also, data of photosynthetic pigments in both intact and infested tomato leaves were subjected to analysis of Independent- Sample T- test using the same statistical program. 


\section{RESULTS AND DISCUSSIONS}

The data in (Table 1) show that the treatment of sprayed during 2016 season with lambda- Cyhalothrin caused the highest reduction inpopulation of B. tabaci population $(94.80 \%)$ within 14 days. Thiamethoxam came in the second position of effectiveness against the population of whitefly, B. tabaci that reduced of the individuals from 3.50 (control) pre-treatment to reached to 0.07 by $75.20 \%$ within 14 days of post-treatment interval compared with acetampride that reduced pre- treatment population of the tested insect pest 4.90 by $(72.03 \%)$ within the same periods of post-treatment interval.

During season 2017, all the treatments were marched on the same trend as mentioned with low fitness. The data (Table 2) show that the treatment with lambda-cyhalothrin gave the highest reduction in $B$. tabaci population followed by thiamethoxam, where it caused reduction in pre- treatment population of whitefly 3.80 by $(68.77 \%$ ), while acetampride caused $63.56 \%$ population reduction within 14 days of post-treatment interval.

Table (3) shows that there were significant differences in the mean content of pigments in both intact and infested tomato leaves. It was observed that the highest content of pigments was in intact tomato leaves $(4.65 \mathrm{mg} / \mathrm{g})$ compared with the mean content of pigments in infested tomato leaves (4.41 $\mathrm{mg} / \mathrm{g}$ ). From the same Table, it is clear that in intact tomato leaves, chlorophyll a was the highest mean content significantly $(9.16 \mathrm{mg} / \mathrm{g})$ compared with chlorophyll a in infested tomato leaves $(8.43 \mathrm{mg} / \mathrm{g})$, then chlorophyll b which was recorded $(2.36 \mathrm{mg} / \mathrm{g})$ in intact tomato leaves, while in case of infested tomato leaves chlorophyll b was $(2.05 \mathrm{mg} / \mathrm{g})$. Looking towards, carotenoids (carotene and Xanthophyll), The results showed that carotene and Xanthophyll in infested tomato leaves was the highest mean content significantly $(2.76 \mathrm{mg} / \mathrm{g})$ compared with carotenoids in intact tomato leaves $(2.714 \mathrm{mg} / \mathrm{g})$.

Neonicotinoids, targeting insect nicotinic acetycholine receptors (nAChRs), have veterinary and crop protection applications, with their actions providing economic benefits. However, their target- selectivity is important to insure safety and to limit adverse effects on benefitial insects such as honeybees. They are agonist of the nAChRs (Tomizawa and Casida, 2003 and Tan et al., 2007) and do not exert as a direct inhibition of the AChE 


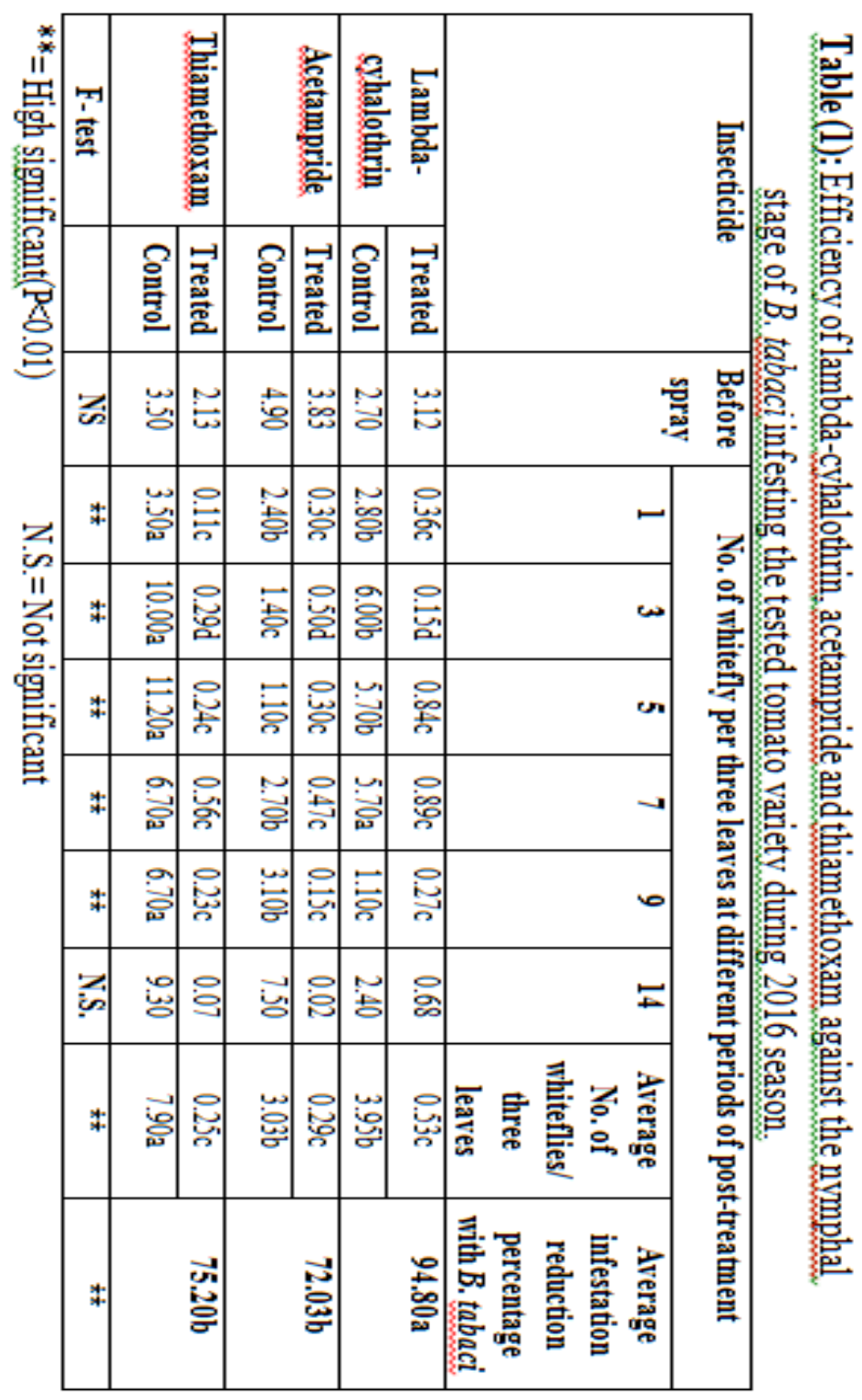




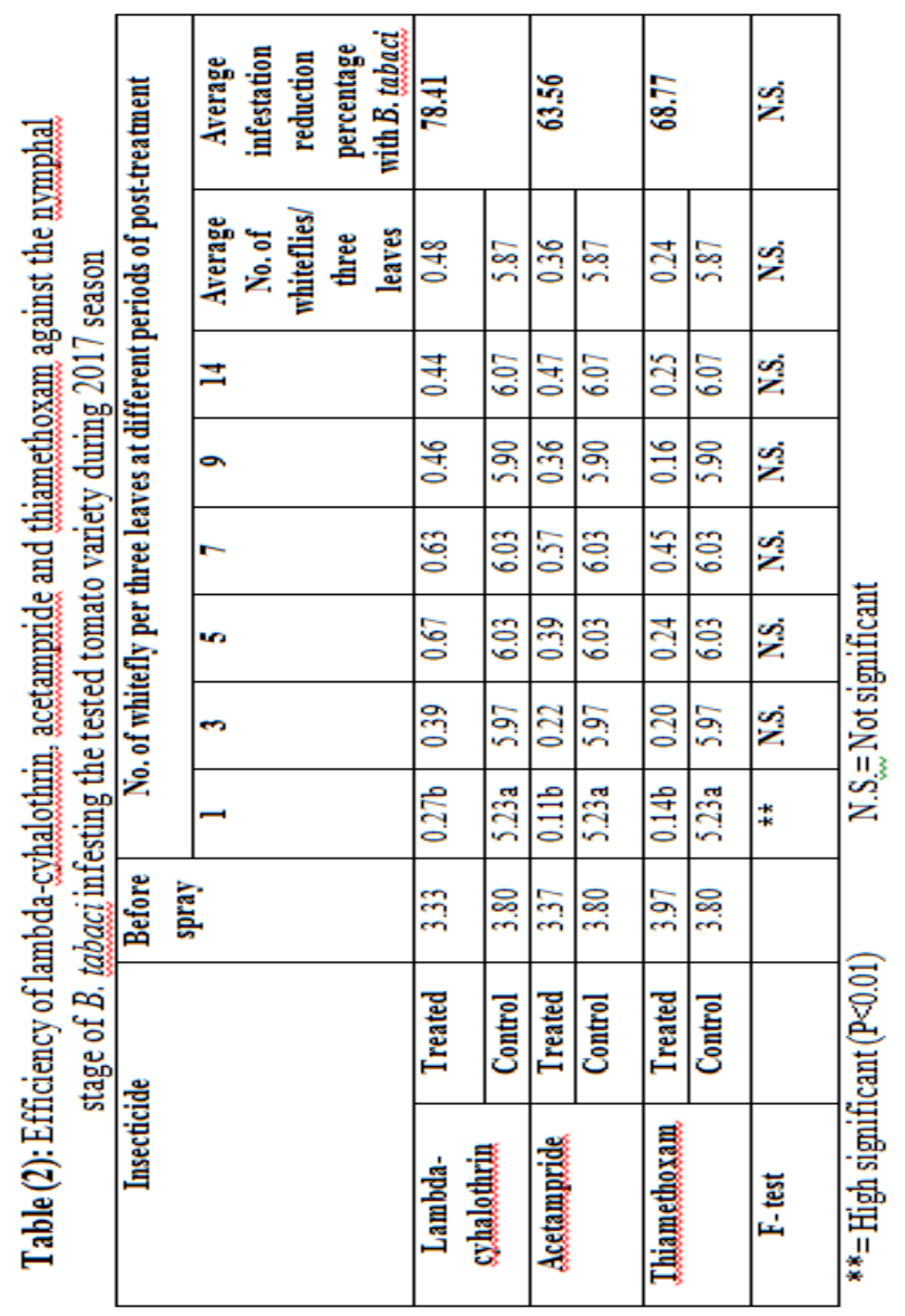


Table (3): Effect of $B$. tabaci infestation on some photosynthetic pigments in tomato leaves.

\begin{tabular}{|l|l|l|l|}
\hline \multicolumn{1}{|c|}{ Photosynthetic pigments } & $\begin{array}{c}\text { Intact tomato } \\
\text { leaves }\end{array}$ & $\begin{array}{c}\text { Infested } \\
\text { tomato leaves }\end{array}$ & $\begin{array}{c}\text { T (value) } \\
\text { calculated }\end{array}$ \\
\hline Chlorophyll a (mg/g) & $9.155 \pm 0.134$ & $8.427 \pm 0.710$ & $3.907^{* *}$ \\
\hline Chlorophyll $\mathrm{b}(\mathrm{mg} / \mathrm{g})$ & $2.355 \pm 0.126$ & $2.053 \pm 0.288$ & $3.717^{* *}$ \\
\hline Carotenes $(\mathrm{mg} / \mathrm{g})$ & $0.122 \pm 0.003$ & $0.138 \pm 0.014$ & $4.486^{* *}$ \\
\hline Xanthophyll $(\mathrm{mg} / \mathrm{g})$ & $2.314 \pm 0.051$ & $2.621 \pm 0.259$ & $4.486^{* *}$ \\
\hline Carptenoids $(\mathrm{mg} / \mathrm{g})$ & & & $4.486^{* *}$ \\
& $2.436 \pm 0.053$ & $2.759 \pm 0.274$ & \\
\hline
\end{tabular}

Tabulated T value at ${ }_{0.05}=2.131$; Tabulated $\mathrm{T}$ value at ${ }_{0.01}=2.947$ and

** Highly significant $(\mathrm{P}<0.01)$

activity as shown for other pesticides. AChE is a key enzyme in the neurotransmission at cholinergic syanapses by rapid hydrolysis of the neurotransmitter acetylcholine to choline and acetate.

Neonicotinoids have several advantages over older classes of insecticides such as their good controlling properties of insect pests at low rates or doses, high levels of selecting, greater specificity to target pests along with low toxicity to non- target organisms and the environment, replaced many old/ conventional compounds (Hara, 2000).

These results are in agreement with several previous studies on toxicity of acetamiprid and or thiamethoxam to $4^{\text {th }}$ instar larvae of insecticide - susceptible strains of S. littoralis and Heliothis virescens (Lagadic et al., 1993); 7 days old larvae of S. litura (Ramanagouda and Srivastava, 2009); eggs of the codling moth, Cydia pomonella (L.) and oriental fruit moth, Grapholita molesta (Busck) (Brunner et al., 2005; Magalhaes and Walgenbach, 2011); egg, 2nd and 4th larval instar of diamondback moth, Plutella xylostella (Yamada et al., 1999).

Generally, based on the chemical structure of the two tested neonicotinoid insecticides, our results reveal that the cyano- substituted compound (acetamiprid) is more toxic to the test insect pests $B$. tabaci than the nitro- 
substituted compound (imidacloprid). The tested neonicotinoids are more effective against the tomato whitefly, $B$. tabaci as compared with lambdacyhalothrin. Moreover, the adults of $B$. tabaci are more sensitive than nymphs.

The results are in accordance with Naggar and Zidan (2013), who reported that imidacloprid and thiamethoxam were the most effective against sucking insec pest like whitefly, jassids and aphids.

The maximum reduction percentage was after 40 days, and it was also observed that imidacloprid was more effective than thiamethoxam on soil fauna. On the other hand, Jamshid et al. (2015) demonstrated that Datura alba (5\%) and $P$. hystophorous (5\%) were more effective against $B$. tabaci compared with imidacloprid (250 g/acre). Asi et al. (2008) tested Confidor (imidacloprid) and Polo (acetamiprid) against whitefly, jassids and thrips, and they found that the previously tested insecticides were very effective against the a fore-mentioned tested insect pests on cotton and tomato crops within 24, 48, 72 and $168 \mathrm{~h}$. Schster et al. (2009) indicated that Megamos (lambda-cyhalothrin) and imidacloprid were more efficacy up to seven days, while Actara (thiamethoxam) was least effective against whitefly on cotton. Mustafa (2000) found that Mospilan (acetampride), polo and confidor (imidaclopride) were the most effectivene, where they gave almost $72.76 \%$ mortality of whitefly. Mohan and Katiyar (2000) tested the efficacy of confide or (imidaclopride) toward whitefly and found that it was the most effective against the tested insect pest in cotton and vegetables but continuous uses of imidacloprid resulted in increased population of whitefly by the development of resistance. Das and Islam (2014), demonstrated that imidacloprid, fipronil and buprofezin were the most effective against whiteflies and jassids, while moderate effectiveness was observed by using thiamethoxam + emamectin benzoate.

Results of the present study showed that feeding of the whitefly, B. tabaci reduced content of plant pigments (chlorophyll $\mathrm{a}$, chlorophyll $\mathrm{b}$ and carotenoids). Direct sucking of plant sap, which contains plant pigments, may cause reducing in these pigments. Walstd et al. (1973) proved that chlorosis in pine leaves resulted by feeding whitefly on phloem sap, which contains water and many important nutrients for plant, especially some minerals such as magnesium, thus destroy chlorophyll. Also, Buntin et al. (1993) proved that nymphal and adult stages of B.tabaci infested tomato. Leaves reduced chlorophyll content and photosynthetic capacity per unit of remaining chlorophyll. Also, Al shareef (2011), in Saudi Arabia, studied the effect of B. tabaci infestation on the mean 
content of plant pigments (chlorophyll a, b and carotene), in the leaves of three different plant varieties (cantaloupe, cucumber and zucchini) in a green house. Results indicated that infestation with this insect pest reduced mean content of each plant pigments in all plant varieties.

Few studies stated that the reduction in the chlorophyll content in infested plant with $B$. tabaci might be caused by presence of tomato yellow mosaic virus, thus causing reduction in photosynthesis rate (Marco, 1975 and Leal and Lastra, 1984). Others, confirmed that the reduction in chlorophyll content was not caused by viruses. (Ac Auslane et al., 2004) conducted experiments on two different genetic types of zucchini one tolerant to silver leaf disorder virus and one susceptible. They found that all genotypes had reduced chlorophyll $a, b$ and carotenoids content reached to $66 \%$ in petioles at the infestation level of 30 pairs of whitefly and their progeny. This means that tolerance to silver leaf disorder virus in zucchini didn't protect. This genotype in reducing certain photosynthetic pigments and photosynthetic induced by feeding of argentifolii, and the reduction in plants pigments was caused by feeding whitefly not by the infestation with silver leaf virus. Jimenez et al. (1995) found that feeding of whitefly, B. tabaci biotype A on squash plant (cucurbita pepo L.) caused chlorosis and decreasing chlorophyll contents furthermore, B. tabaci causing significant reduction reached to $97 \%$ and $65.9 \%$ in each of chlorophyll content and photosynthesis rate, respectively, in eggplant leaves (Touhidul Islam and Shunxiang, 2009). Also, shannag and Freihat (2009) stated that B. tabaci infestation on cucumber leaves caused $30 \%$ reduction in the photosynthetic rate at 14 days after whitefly release. Some insects feeding in the same way of the whiteflies causing the same effect (Ni et al., 2001 and $\mathrm{Ni}$ et al., 2002) reported that aphids, Dluraphis noxia and Rhopalosiphum padi, caused reduction in amount of chlorophyll a , b and carotenoids, and increased chlorophyll degradation enzyme of infested wheat leaves.

In summary, the present results indicate that all the tested insecticides were effective in reducing $B$. tabaci infestation in both the two seasons. Lambdacyhalothrin proved most promising and caused $86.60 \%$ reduction in $\mathrm{B}$. tabaci infestation in comparison with thiamethoxam which caused $71.99 \%$. Acetampride was least effective with infestation reductions of $67.80 \%$. Respecting the impact of B.tabaci infestation on tomato leave s pigments, our results indicate that there were highly significant differences between intact tomato leaves and infested tomato leaves. The higher mean content of pigments 
was in intact tomato leaves $(4.65 \mathrm{mg} / \mathrm{g})$ as compared with the mean content of pigments in infested tomato leaves $(4.41 \mathrm{mg} / \mathrm{g})$.

In conclusion, it could be recommended using lambda-cyhalothrin besides thiamethoxam in combating the tomato whitefly, B. tabaci, in integrated pest management (IPM).

\section{REFERENCES}

Al-Shareef, L.A.H. (2011). Impact of whitefly, Bemisia tabaci (gennadius) infestation on chlorophyl and carotene concentrations, as well as moisture content in some vegetable plants in a greenhouse. Egypt. J. Exp. Biol. Zool., 7(1): $11-15$.

Asi, M.R., M. Afzal, S.A. Anwar and M.H. Bashir (2008). Comparative efficacy of insecticides against sucking insect pests of cotton. Pak. J. L. Soc. Sci., 6 (2):140-142.

Boykin, L.M., R.G. Shatters, R.C. Rosell, C.L. McKenzie, R.A. Bagnall, P. De Barro and D.R. Frohlich (2007). Global relationships of Bemisia tabaci (Hemiptera: Aleyrodidae) revealed using Bayesian analysis of mitochondrial COI DNA sequences. Mol. Phylogenet. Evol., 44(3): 13061319.

Brunner, J.F., E.H. Beers, J.E. Dunley, M. Boerr and K. Granger (2005). Role of neonicotinyl insecticides in Washington apple integrated pest management. Part 1. Control of Lepidopteran pests. Journal of Insect Science, 5:14, 10pp. available online: insectscience. Org/5.14.

Buntin, G.D., D.A. Gilbertz and B.D. Oetting (1993). Chlorophyll loss and gas exchange in tomato leaves after feeding injury by Bemisia tabaci (Homoptera: Aleyrodidae). J. Econ. Entomol., 86(2): 517-522.

Cahill, M., W. Jarvis, K. Gorman and I. Denholm (1996). Resolution of baseline responses and documentation of resistance to buprofezin in Bemisia tabaci (Homoptera: Aleyrodidae). Bulletin of Entomological Research, 86: 117-122.

Das, G. and T. Islam (2014). Relative efficacy of some newer insecticides on the mortality of jassid and whitefly in brinjal. International Journal of Research in Biological Sciences, 4(3):89-93. 
Dempsey, M., D.G. Riley and R. Srinivasan (2017). Insecticidal effects on the spatial progression of tomato yellow leaf curl virus and movement of its whitefly vector in tomato. J. Econ. Entomol., doi: 10.1093/jee/tox061.

Denholm, I., M. Cahill, F. Byrne and A.L. Devonshire (1996). Progress with documenting and combating insecticide resistance in Bemisia. In: "Taxonomy Biology, Damage, Control and Management, (Gerling D, Mayer R. Ed.)", Intercept, Ltd., Andover, UK, 577-603.

Dinsdale, A., L. Cook, C. Riginos, Y.M. Buckley and P. De Barro (2010). Refined global analysis of Bemisia tabaci (Hemiptera: Sternorrhyncha: Aleyrodoidea: Aleyrodidae) mitochondrial cytochrome oxidase 1 to identify species level genetic boundaries. Ann. Entomol. Soc. Am., 103(2): 196-208.

Global Invasive Species Database (GISD) (2012). Bemisia tabaci. http://www.issg.org/database/species/ecology.asp?si=106\&fr=1\&sts=\&lan $\mathrm{g}=\mathrm{EN}$ [Accessed 22 July 2012].

Hameed, A., M.A. Aziz and G.M. Abeer (2010). Susceptibility of Bemisia tabaci Gen. (Homoptera: Aleyrodidae) to selected insecticides. Pakistan Journal of Zoology, 42(3): 295-300.

Henderson, C.F. and E.W.Tilton (1955). Tests with acaricides against the brow wheat mite. J. Econ. Entomol., 48: 157-161.

Herbert, K.S., A.A. Hoffmann and K.S. Powell (2008). Assaying the potential benefits of thiamethoxam and imidacloprid for phylloxera suppression and improvements to grapevine vigour. Crop Prot., 27:1229-1236.

Jamshid, A., A.R. Saljoqi, R.A. Shah, M. Salman, A.Z. Shah and S. Anwar (2015). Comparison of two botanical extracts with Imidacloprid in suppressing cotton whitefly, Bemisia tabaci Gennadius (Hemiptera: Aleyrodidae). J. Entomol. Zool. Studies, 3(3):215-217.

Jimenez, D.R., R.K. Yokomi, R.T. Mayer and J.P. Shapiro (1995). Cytology and physiology of silver leaf whitefly-induced squash silver leaf. Physiol. Mol. Plant Pathol., 46(3): 227-242.

Lagadic, L., A. Cuvany, J. Berge and M. Echaubard (1993). Purification and partial characterization of glutathione-s- transferase from insecticideresistance and lindane induced susceptible Spodoptera littoralis (Boisd.) larvae. Insect Biochemistry and Molecular Biology, 23: 467-474.

Leal, N. and R. Lastra (1984). Altered metabolism of tomato plants infected with tomato yellow mosaic virus. Physiol. Mol. Plant Pathol., 24(1): 1- 7. 
Lichtenthaler, H.K. (1987). Chlorophylls and carotenoids: pigments of photosynthetic biomembranes. Method. Enzymol., 148:350-382.

Magalhaes, L.C. and J.F. Walgenbach (2011). Life stage toxicity and residual activity of insecticides to codling moth and oriental fruit moth (Lepidoptera: Totricidae). Journal of Economic Entomology, 104 (6): 1950-1959.

Mann, R.S., D.J. Schuster, R. Cordero and M. Toapanta (2012). Baseline toxicity of spiromesifen to biotype of Bemisia tabaci in Florida. Florida Entomologist, 95 (1): 95-98.

Marco, S. (1975). Chlorophyll content of tomato yellow leaf curl virus-infected tomatoes in relation to virus resistance. Phytoparasitica, 3(2): 141- 144.

McAuslane, H.J., J. Chen, R.B. Carle and J. Schmaslstig (2004). Influence of Bemisia argentifolii (Homoptera: Aleyrodidae) infestation and squash sliver leaf disorder on zucchini seedling growth. J. Econ. Entomol., 97(3): 1096-1105.

Mohan, M. and K.N. Katiyar (2000). Impact of different insecticides used for bollworm control on the population of jassids and whitefly on cotton. $J$. Pestic. Res., 12(1):99- 102.

Mustafa, G. (2000). Annual Report Entomology Section, Ayub Agric. Res. Institute, Faisalabad, 1-14.

Naggar, N.J.B. and N.E.H.A. Zidan (2013). Field evaluation of Imidacloprid and Thiamethoxam against sucking insects and their side effects on soil fauna. J. Plant Prot. Res., 53(4):375-387.

Nauen, R., H.J. Schnorbach and A. Elbert (2005). The biological profile of spiromesifen (Oberon)- a new tetronic acid insecticide/ acaricide. Pflanzenschutz Nachrichten Bayer, 58: 417-440.

Nauen, R., U.L. Ebbinghaus-Kintscher, V. Salgado and M. Kaussmann (2003). Thiamethoxam is a neonicotinoid precursor converted to clothianidin in insects and plants. Pestic. Biochem. Physiol., 76(2):55-69.

Ni, X., S.S. Quisenberry, J. Markwell, T. Heng-Moss, T. Higley, F. Baxendale, G. Sarath, and R. Klucas (2001). In vitro enzymatic chlorophyll catabolism in wheat elicited by cereal aphid feeding. Entomol. Exp. Appl., 101: 159-166.

Ni, X., S.S. Quisenberry, T. Heng-Moss, J. Markwel, L. Higley, F. Baxendale, G. Sarath and R. Klucase (2002). Dynamics change in photosynthetic pigments and chlorophyll degradation elicited by cereal aphid feeding. Entomol. Exp. Appl., 105: 43-53. 
Radwan, E.M.M. and H.S. Taha (2012). Toxic and biochemical effects of different insecticides on the tomato leafminer, Tuta absoluta (Meyrick) (Lepidoptera: Gelechiidae). Egypt. Acad. J. Biol. Sci., 4 (1): 1- 10.

Ramanagouda, S.H. and R.P. Srivastava (2009). Bioefficacy of insecticides against tobacco caterpillar, Spodoptera litura. Indian Journal of Plant Protection, 37: 14-19.

Schuster, D.J., R.S. Mann, M. Toapanta, R. Cordero and S. Thompson (2010). Monitoring neonicotinoid resistance in biotype B of Bemisia tabaci in Florida. Pest Manag. Sci., 66:186-195.

Schuster, D.J., S.K. Alb and A. Shurtleff (2009). Silver leaf whitefly and TYLCV control on fresh market tomatoes with soil and foliar insecticide applications. Arthropod. Manag. Tests, 34(1):E80.

Shannag, H.K. and N.M. Freihat (2009). Gas exchange of cucumber, Cucumis sativus L., impaired by tobacco whitefly, Bemisia tabaci (Gennadius) (Hemiptera: Aleyrodidae). Jordan. J. Agric. Sci., 5(3): 295-305.

Sharma, K. and S. Chander (1998). Spatial distribution of jassid Amrasca and Biguttula biguttula (Ishida) on cotton. Ind. J. Ent., 60(4):326-328.

Tan, J., J.J. Galliganb and R.M. Hollingwortha (2007). Agonist actions of neonicotinoids on nicotinic acetylcholine receptors expressed by cockroach neurons. NeuroToxicology, 28 (4): 829-842.

Tomizawa, M. and J.E. Casida (2003). Selective toxicity of neonicotinoids attributable to specificity of insect and mammalian nicotinic receptors. Annual Review of Entomology, 48: 339-364.

Toscano, N., T. Henneberry and S. Castl (1994). Population dynamics and pest status of silver leaf whitefly in the U.S.A. Arab J. Pl. Prot., 12(2): 137-142.

Touhidul, I.M.D. and R. Shunxiang (2009). Effect of sweet potato whitefly, Bemisia tabaci (Homoptera:Aleyrodidae) infestation on eggplant (Solanum melongena L.) leaf. J. Pest Sci., 82(3): 211-215.

Walstad, J.D., D.G. Nielsen and N.E. Johnson (1973). Effect of the pine needle scale on photosynthesis of Scots pine. Forest Sci., 19(2): 109-111.

Yamada, T., H. Takahashi and R. Hatano (1999). A novel insecticides, acetamiprid. In: Nicotinoid Insecticides And The Nicotinic Acetylcholine Receptor. In 1. Yamamoto and J.E. Casida (ed.). Springer, Tokyo, pp. 149176. 


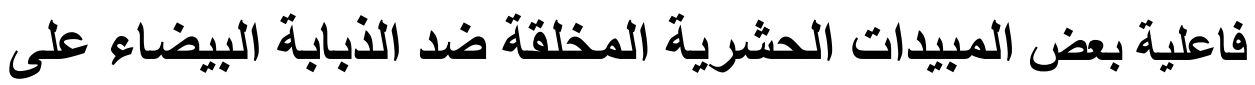

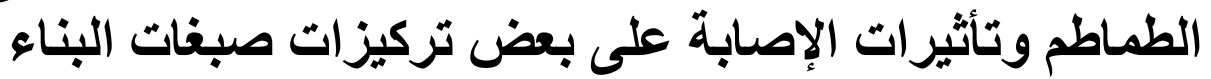 الضوئي في أوراق نباتات الطماط نركيز
}

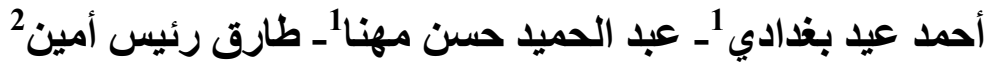

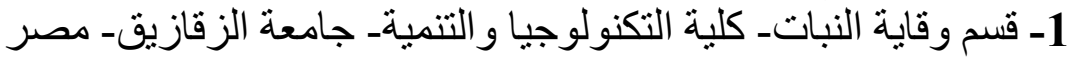

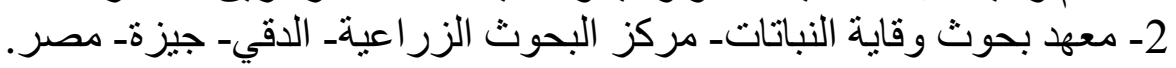

أُجريت التجارب الحقلية خلال موسمي 2016 و 2017 فى قرية القرين محافظة الثرقية لتقييم فاعلية بعض الثبارية المبيدات الحشرية المخلقة المستخدمة (اللمبدا-

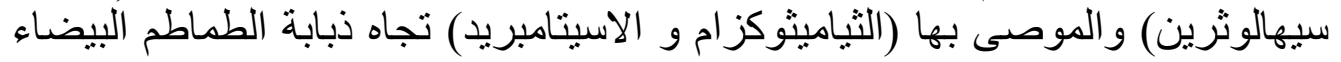

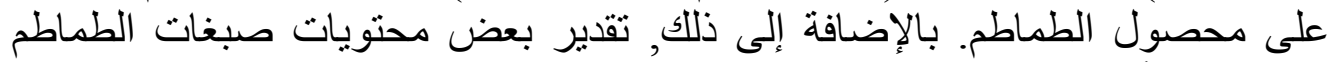

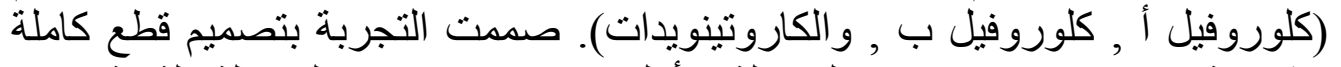

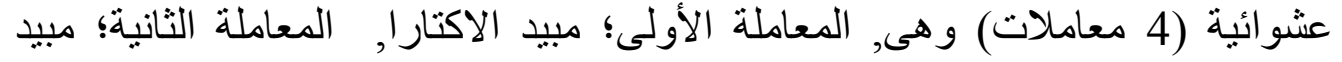

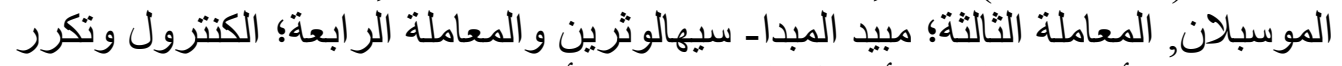

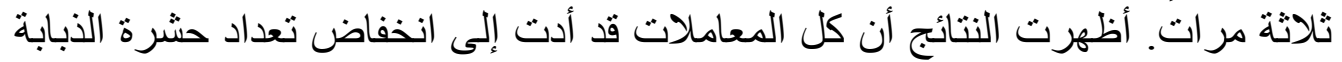
البيضاء خلال الرشة الأولى، الثانية والثانية الثالثة.

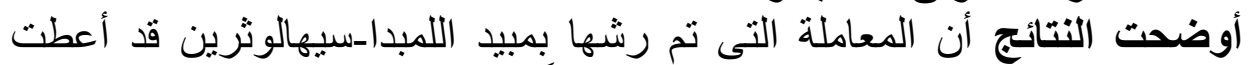
الأعلى إنخفاض في تعدادات الدبابة البيضاء منبو عاً بمبيدي الثياميثوكز النيام و الاسيتامبريد

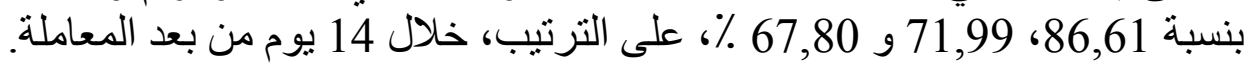

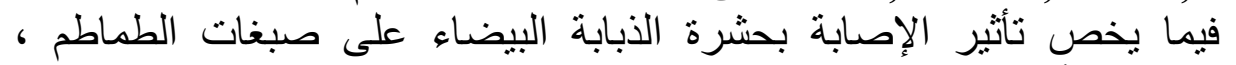

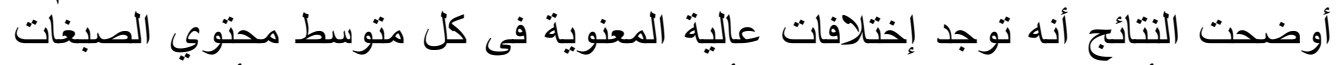

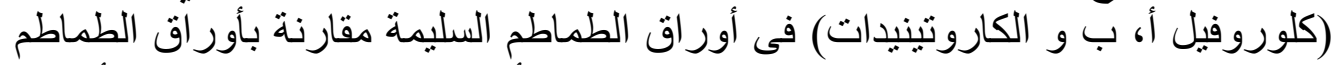

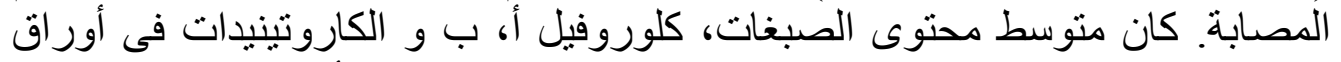

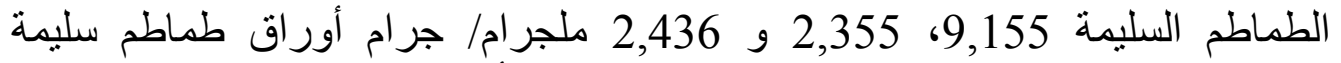

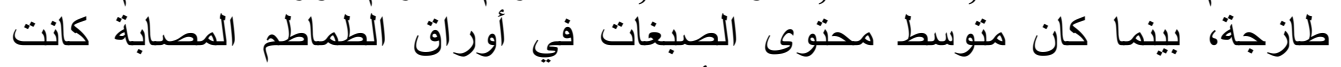

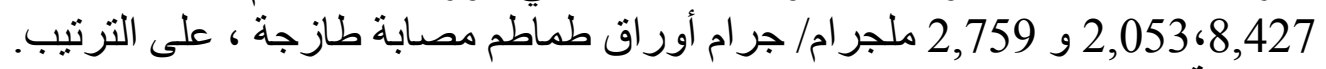

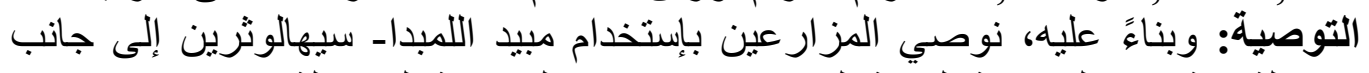
مبيد الثياميثوكز ام لمكافحة الذبابة البيضاء في براء برنامج المكافحة المتكاملة. 